\title{
Economic Development Incentives: Research Approaches and Current Views
}

Dan Gorin, of the Board's Division of Consumer and Community Affairs, prepared this article.

Economic development incentives-state and local government efforts to encourage economic development - are one of a limited number of tools local policymakers have for stimulating local economies. Some broad measures-investments in infrastructure (such as transportation), human capital (education, for example), and social infrastructure (such as recreational facilities) - may produce significant results over the long term. Targeted measures crafted to attract or retain businesses-usually a tax preference or financial assistance-offer the possibility of a quick payoff.

Public interest in incentives has generally been muted, except when very generous incentive packages, egregious practices, or legal issues have prompted questions about their appropriateness and effectiveness. Policymakers struggling with practical decisions have frequently turned to economists for guidance: Should incentives be offered? If so, how large should they be? And how can an incentive program be designed to increase its effectiveness? Much of the research assessing the effectiveness of incentives has been inconclusive or unsatisfactory, in part because of methodological flaws and inadequate data.

Interest in incentives surged in the 1980s and 1990s as a result of very public bidding wars among localities to entice businesses to their communities. In particular, the dollar amount of incentive packages offered to automobile manufacturers looking to locate new facilities soared during that period. In 1980, Nissan received an estimated $\$ 33$ million, or $\$ 8,000$ per anticipated job, for locating a new facility in Tennessee. The amount of subsequent incentive packages handed out to Mazda, Saturn, DiamondStar, and Toyota, among others, rose over the next few years, and by 1987, Toyota was receiving an estimated $\$ 150$ million, or $\$ 50,000$ per anticipated job, for locating a new facility in Kentucky. ${ }^{1}$ And the incentive packages were growing again before long. Although BMW's 1992 package to locate in South Carolina was reportedly just $\$ 150$ million, MercedesBenz reportedly received $\$ 258$ million the next year to locate a facility in Alabama. ${ }^{2}$

News accounts of ever-larger incentive packages caught the attention of economists and policymakers as well as the public. An essay entitled "Congress Should End the Economic War among the States" appeared in the 1994 Annual Report of the Federal Reserve Bank of Minneapolis. ${ }^{3}$ A few years later, a conference on the same topic brought together policymakers, economists, tax experts, economic developers, and business-site location consultants from around the country to discuss the matter. ${ }^{4}$ Many questions were raised, and research goals were identified, among them the goal of establishing good data with which to answer the economic questions.

In the past ten years, case studies, input-output analyses, and other research techniques have addressed some of the methodological flaws of earlier incentives studies. The availability of better data on both incentives and economic activity has also improved analyses of incentives research. The work described in this article illustrates some of the fresh ways that researchers have found to look at the effectiveness of incentives. The focus is not on proving or disproving the effectiveness of incentives as a

1. Jeffrey A. Finkle (1996), "Location Incentives Are Unfair and Poorly Justified," pp. 1-2, www.developmentalliance.com/docu/pdf/ 43300.pdf.

2. A detailed case study of the location of automobile assembly plants can be found on the Good Jobs First website at www.goodjobsfirst.org/corporate_subsidy/ automobile_assembly_plants.cfm.

3. Melvin L. Burstein and Arthur J. Rolnick (1994), "Congress Should End the Economic War Among the States," Essay in 1994 Annual Report of the Federal Reserve Bank of Minneapolis, www.minneapolisfed.org/pubs/ar/ar1994.cfm?js $=0$

4. The conference, held in Washington, D.C., on May 21-22, 1996, was hosted by Minnesota Public Radio's Civic Journalism Initiative. For more information, see www.minneapolisfed.org/publications papers/studies/econwar/index.cfm and related links. 
means of spurring economic development. Rather, the intent is to demonstrate that new ways are being used to advance the discussion.

\section{THE CONVENTIONAL WISDOM, TEN YEARS AGO}

In the 1990s, many academics and policymakers expressed skepticism that state and local economic development incentives could induce firms to add jobs or invest in a particular locality. At the time, researchers tended to conclude that incentives were marginally effective at best. Such conclusions appeared to corroborate the general notion that incentives in the form of state and local tax breaks are ineffective because state and local taxes typically constitute a small portion of a business's overall costs. Furthermore, critics argued, if the incentives increased the amount of income or profit subject to federal income tax, a considerable portion of the amount saved through state and local tax relief would likely be offset by higher federal taxes.

Much research during the 1980s and 1990s was based on flawed data or used independent variables that did not accurately represent the dollar amount of incentives. For example, several studies used the number of incentive programs on a state's books as a proxy for the state's total development effort. But often this number does not provide a complete picture. Many states have on their books incentive programs that are dormant, unfunded, or known to be ineffective. And some states treat their incentives as multiple programs, while others provide the same benefits within a single program.

Other early research on incentives used the budget of a state's lead development agency as a proxy for development efforts. However, that amount is rarely an accurate indicator of the amount spent directly on incentives. For example, development agency funds are typically used for other aspects of development, such as marketing and staff payroll. Development agency funds are also likely to be used for activities not directly related to business development, such as housing development or the promotion of tourism. Moreover, funding for incentives may not come from a development agency's budget. If the incentive takes the form of a tax preference, an appropriation may not be necessary. And if an appropriation is necessary, the funding for incentives may come from the budget of a different agency, such as education or transportation.

Economic development data concerning the state of Oklahoma, provided by the National Association of State Development Agencies (NASDA), illustrate the inadequacy of some data collection efforts.
According to NASDA, the state spent $\$ 20.45$ million on economic development in fiscal 1997. But this amount was simply the budget for the Oklahoma Department of Commerce, the state's lead development agency. The state's single largest incentive that year-worth just more than $\$ 1$ billion-was a set of sales tax exemptions available to all manufacturers for purchasing machinery, equipment, and goods used and consumed in manufacturing. An argument could be made that these sales tax exemptions were not truly incentives and, therefore, were appropriately not included in the NASDA total because they were nondiscretionary and fairly common among the states. But there are other reasons to view the single NASDA figure as inadequate. The most promoted incentive in Oklahoma in fiscal 1997-a wage subsidy offered under the state's Quality Jobs program — cost the state $\$ 21.1$ million that year. But again, that amount was not part of the Department of Commerce's budget. A second incentive, a local property tax abatement costing $\$ 14.8$ million in fiscal 1997, was a budget item at the state level, as the state reimbursed local governments providing the incentive; but this incentive was also not in the department's budget. A third incentive in fiscal 1997-\$13.2 million in tax credits for investment and job creation-was a standard tax preference, not an appropriated expenditure. Clearly, the use of a narrowly focused budget figure as a proxy for the state's financial commitment to its major incentives, while seemingly logical, is problematic, and it is unlikely to result in meaningful conclusions as to the benefits of the incentives.

\section{THE SEARCH FOR A BETTER RESEARCH DESIGN}

The work of several researchers began to change the conventional wisdom that business incentives were marginally effective at best, as Fisher and Peters noted in $1997 .{ }^{5}$ By conducting and identifying studies that used more-detailed data and more-refined techniques, Newman and Sullivan compiled evidence of the effectiveness of incentives. ${ }^{6}$ Bartik's contribution to incentives research was twofold: his comprehensive literature review brought to light a substantial body of work - released up through the early 1990s-

5. Peter S. Fisher and Alan H. Peters (1997), "Tax and Spending Incentives and Enterprise Zones," New England Economic Review (March-April), pp. 109-130, www.bos.frb.org/economic/neer/ neer1997/neer297f.pdf.

6. Robert J. Newman and Dennis H. Sullivan (1988), "Econometric Analysis of Business Tax Impacts on Industrial Location: What Do We Know, and How Do We Know It?" Journal of Urban Economics, vol. 23 (2), pp. 215-234. 
that tracked the relationship between incentives and state and local development; furthermore, his systematic analysis of such variables as employment, home prices, and wages in metropolitan areas illustrated the effect on these variables of economic growth that may result from incentives and other development efforts. ${ }^{7}$

\section{Defining Economic Development Incentives}

Although research on incentives improved through the 1990s, more clarity was needed to ensure that studies were based on complete data. At the root of the problem, as the Oklahoma example shows, was the lack of a comprehensive definition for "economic development incentives." Fisher and Peters clarified the problem by identifying five categories of incentives: ${ }^{8}$

1. one-time deals negotiated with individual firms,

2. grants and loans provided under programs that receive annual state appropriations,

3. programs establishing parameters and limits but allowing some degree of local government discretion,

4. incentives that function as entitlements, whereby a firm receives the benefit automatically provided its investment is in an eligible sector and the size of the investment or number of new jobs created exceeds some threshold, and

5. code features that apply to all firms, but benefit some more than others and are often advertised by economic development agencies as reasons to locate in a state.

To this list might be added changes to state statutes that have the effect of opening markets to firms in particular industries. Examples include statute changes to allow certain industries, such as corporate farming, to begin or expand operations in a state; changes to the apportionment formula for corporate income taxes (to be discussed later); and relaxation of state usury limits. ${ }^{9}$

7. Timothy Bartik (1991), "Who Benefits from State and Local Economic Development Policies?" Upjohn Institute.

8. Fisher and Peters, "Tax and Spending Incentives and Enterprise Zones."

9. Delaware and South Dakota, for example, relaxed their usury limits in an effort to induce large banks to locate their credit card operations within state borders - an effort that proved successful, as evidenced by the cluster of large banks with high credit card volumes located in Delaware and the South Dakota return address on many credit card statements. For more information, see Steve Young (2002), "Repealed Usury Law Helped Lure Industry," Argus Leader, March 24; and Diane Ellis (1998), "The Effect of Consumer Interest Rate Deregulation on Credit Card Volumes, Charge-Offs, and the Personal Bankruptcy Rate," FDIC Bank Trends Series 98-05 (Washington, D.C.: Federal Deposit Insurance Corporation, March), www.fdic.gov/ bank/analytical/bank/bt_9805.html.
Fisher and Peters noted that public interest in economic development incentives tends to focus on one-time deals (category 1). ${ }^{10}$ Much of the research on incentives, however, has focused on tax-related issues (categories 4 and 5), in part because identifying special provisions in state tax codes, and then calculating effective tax burdens, is generally easier than analyzing data for all the negotiated deals within a specific geographic region or for a particular type of program (assuming that all such data can even be amassed). Yet when a study considers only tax incentives offered by a state and ignores local or nontax incentives, any conclusions will likely be faulty, as research has shown that local and nontax incentives can easily account for more than half the value of an incentive package.

The following examples, based on actual state and local incentives, illustrate the need to consider the specifics of an incentive package. The first case involves property taxes, and the second, sales taxes.

- In one locality, a firm receives a property tax abatement on a building (category 3); in a second locality, a firm automatically qualifies for a similar abatement (category 4); and in a third locality, a firm receives reduced rent in a building owned by an industrial authority and not on the property tax rolls (category 1). The reported value of these commonly offered incentives may be the same, but researchers using different definitions or having incomplete information may reach very different conclusions about the effectiveness of these property tax incentives.

- One state has a sales tax provision that exempts, at all times, all purchases by manufacturers of new and used machinery and equipment; another state exempts purchases of only new machinery and equipment; a third state exempts purchases only when a facility is built; and a fourth state limits the exemption to certain geographic areas and to only those firms that apply for it. Once again, analyses that do not account for the differences among incentive programs across jurisdictions may reach different conclusions about the effectiveness of those programs.

\section{IMPROVING INCENTIVES RESEARCH: REFINED APPROACHES, BETTER DATA SOURCES}

Researchers have taken a number of approaches to measuring the effectiveness of incentives. Economet-

10. Fisher and Peters, "Tax and Spending Incentives and Enterprise Zones." 
ric modeling has been a common approach, albeit one with weaknesses. Misspecification of variables, for example, can be a serious problem. Consider the various property tax incentives in the first of our prior examples. A model looking at only tax-based incentives will not capture the third type of property tax incentive described, whereby the building is kept off the property tax rolls altogether. Similarly, a model that incorporates only state-level tax incentives may be incomplete if local incentives constitute a large portion of an incentive package (as might be the case in the first type of property tax incentive described earlier). However, when the incentives studied are carefully identified and the data used are known to accurately represent the total incentive package, econometric modeling can provide a reliable picture of the effectiveness of incentives. Models are often used in conjunction with other research approaches, such as case studies and input-output analyses. In addition, incentives studies using all of these approaches may tap national, state, or local data sets.

\section{Case Studies: Varied Approaches to Analyzing Incentives}

Fisher and Peters created a hypothetical manufacturing firm, and then used a case-study approach to look at the effects of the incentives offered by enterprise zones in more than 20 states and 100 cities. ${ }^{11}$ They considered the details of the many incentive programs they studied, specifically taking into account the type and dollar amount of the incentives. This specificity in defining the study's variables is notable. Fisher and Peters found that such incentives cut the firm's combined state and local taxes, on average and as a percentage of its new investment, by some 20 percent. Nevertheless, they believed the effect was too small to affect business-location decisions.

Using the actual example of General Motors, Bartik looked at several competing incentive packages and analyzed the benefit to the automaker (in terms of its estimated transportation, labor, and tax costs) of locating its Saturn plant in Spring Hill, Tennessee. ${ }^{12}$ This actual case study is useful because it is limited to a specific firm and a finite number of locations. In another specific state case study, Loh considered the incentives offered by different communities within

11. Fisher and Peters, "Tax and Spending Incentives and Enterprise Zones." Enterprise zones are areas specially designated for development for various reasons. Businesses locating in enterprise zones are typically exempt from certain taxes and receive other economic assistance.

12. Timothy Bartik (1991), "Who Benefits from State and Local Economic Development Policies?"
Ohio. ${ }^{13}$ Limiting her analysis to one state allowed Loh to examine multiple categories of incentives available to businesses. Bartik's case study gauged effectiveness by determining whether the presence of an incentive made a particular location a better choice for General Motors than competing locations. Looking at effectiveness from a different perspective, Loh measured effectiveness in terms of the effect (such as employment growth or increased tax receipts), if any, on local economies. For a variation on Loh's approach, see the box "The Texas Local Economic Development Sales Taxes," which describes a case study focusing on a homogeneous region.

\section{Input-Output Analyses: Examining Linkages}

Some recent studies employed input-output analyses to examine how an incentive offered to a single large firm can ripple through an economy, in turn affecting such economic indicators as regional income and employment. Alwang, Peterson, and Mills reported on one such study, by the Virginia Economic Development Partnership, and then conducted further analysis. ${ }^{14}$ The initial study was conducted in compliance with a Virginia requirement that a return-oninvestment analysis be undertaken whenever state funds are to be used in an incentive package offered to a single firm. Alwang, Peterson, and Mills explain that they used Implan computer software to "examine the linkages between the firm in question and its suppliers, and expenditure patterns of people who earn incomes from the firm." 15 Their further analysis is significant because they were able to identify both the losers (such as firms that compete with the business being recruited) and winners (such as suppliers to the newly relocating firm and purchasers of its output) resulting from the awarding of an incentive.

Dauffenbach and Warner also used Implan software, in their case to develop a framework from which to study two of Oklahoma's largest state-level development incentives: wage subsidies provided under the "Quality Jobs" program and an exemption from the ad valorem tax. ${ }^{16}$ They quantified the fiscal

13. Eng Seng Loh (1993), "The Effects of Jobs-Targeted Development Incentive Programs," Growth and Change, vol. 24 (Summer), pp. $365-83$.

14. Jeffrey Alwang, Everett B. Peterson, and Bradford Mills (2001), "Assessing the Impacts of Incentives to Attract New Businesses: A Case Study of the Scrap Recycling Industry" (October 23). Preliminary report available at dls.state.va.us/pubs/hjr157.pdf.

15. Alwang, Peterson, and Mills, "Assessing the Impacts of Incentives to Attract New Businesses" p. 36.

16. Robert C. Dauffenbach and Larkin Warner (2004), "Oklahoma's Ad Valorem Tax Exemptions and the Quality Jobs Act: Analysis of Economic Impacts and Tests for Differential Growth," in Robert Dauffenbach, Alexander Holmes, Ronald L. Moomaw, Kent W. Olson, 
benefits and costs of the two incentives and used the results to determine the incentives' effectiveness. For the Quality Jobs program, they calculated a benefitcost ratio of 6.60; in other words, each direct dollar of incentive spending was associated with $\$ 6.60$ of increased tax revenue. They then examined statelevel employment data and found that industries that received large shares of Quality Jobs payments grew much faster than the national average for those industries. ${ }^{17}$ Using the same approach to look at the ad valorem tax exemption, Dauffenbach and Warner concluded that it is a drag on the state budget and "fares poorly."

In the Oklahoma example, input-output analysis allowed Dauffenbach and Warner to estimate the state's rate of return on its investment in the two development incentive programs. The data generated by such an analysis can also be used to address the "but-for" question: but for the presence of the wage subsidies provided under the Quality Jobs program and by the tax exemption, would the employment gains have occurred? In other words, were these incentives a factor in the decision to invest in Oklahoma? Although it is a fundamental question in incentives policy, researchers have had a very difficult time answering the but-for question. No one has yet been able to create a research design that randomly assigns control and treatment groups. Still, Dauffenbach and Warner were able to quantify the economic and fiscal effects of growth likely induced by an incentive. Making the connection between incentives and growth, though, is still an educated conjecture.

\section{Data-Driven Analyses: Examining Recently Available Data Sets}

Many studies glean information from a local, state, or national data set. These data sets are a relatively new resource; many were unavailable to researchers until the mid-1990s. The included Texas case study lists local data from cities that did and did not adopt special taxes in order to analyze the effectiveness of the state's economic development sales taxes. In another study not explicitly considering incentivesrather it served as an examination of the effects on

and Larkin Warner, State Policy and Economic Development in Oklahoma: 2004 (Oklahoma City: Oklahoma 21st Century, Inc.), pp.13-27, www.okstatechamber.com/file_upload/OK21st2004.pdf.

17. Dauffenbach and Warner's results are consistent with earlier survey work by Gorin suggesting that about half of all jobs in the Oklahoma program were induced by the presence of the incentive. See Dan Gorin (2000), "State Economic Growth Incentives and the Oklahoma Quality Jobs Program," Oklahoma Policy Studies Review, vol. 1, (Spring-Summer), pp. 7-12, www.libarts.ucok.edu/opsa/OPSR/ Journal\%20Vol1-Number1/page7-12.pdf. county employment-Edmiston used data on investments announced by firms adding at least 300 jobs at new or existing facilities in Georgia. ${ }^{18}$ He corroborated the announcement data using state administrative records. Edmiston found that existing business expansions had a greater net effect on county employment than did the creation of new locations. This finding suggests that recruited businesses can crowd out local investment, resulting in smaller (though still positive) benefits for job growth.

Lee used a confidential national data set, the Longitudinal Research Database (LRD) compiled by the Census Bureau, which includes information from the quinquennial Census of Manufacturing. ${ }^{19}$ This database allowed Lee to look at the effects of the initial locations and relocations of plants owned by manufacturing firms having multiple plants throughout the United States. Lee concluded that, for the years 1972 through 1992, plants located in states that implemented new incentive programs tended to increase total employment, capital, and output only slightly more than plants in other states.

Greenstone and Moretti drew on another national database in order to look at the siting of new, "million-dollar facilities" throughout the United States. ${ }^{20}$ Using information from Site Selection magazine on "winning" and "runner-up" counties, in combination with other data, they were able to measure the consequences of a county winning such a facility. According to Greenstone and Moretti, winning counties had greater increases than corresponding runner-up counties in property values, wages, and local government revenues and expenditures in the years following a location. They noted that the possibility of winning a plant location invariably prompted competitions between jurisdictions as they tried to develop more-attractive tax packages for businesses.

\section{New Tools and Resources: Providing Better and More-Comprehensive Analysis}

The 1996 "War Among the States" conference called on state governments and other agencies to develop better information on the costs and benefits of eco-

18. Kelly Edmiston (2004), "The Net Effects of Large Plant Locations and Expansions on County Employment," Journal of Regional Science, vol. 44 (2), pp. 289-319.

19. Yoonsoo Lee (2004), "Geographic Redistribution of U.S. Manufacturing and the Role of State Development Policy," Working Paper 04-15 (Cleveland: Federal Reserve Bank of Cleveland, December), www.clevelandfed.org/Research/Workpaper/2004/WP04-15.pdf.

20. Michael Greenstone and Enrico Moretti (2004), "Bidding for Industrial Plants: Does Winning a 'Million Dollar Plant' Increase Welfare?" MIT Working Paper Series 04-39, (Cambridge, Mass.: Massachusetts Institute of Technology, November). 


\section{The Texas Local Economic Development Sales Taxes}

In 1989, the Texas legislature amended existing state law to allow cities meeting certain criteria to adopt a dedicated sales tax to fund industrial development projects. ${ }^{1}$ Follow-up legislation in 1991 allowed cities to adopt a sales tax dedicated to quality-of-life improvements. These two programs - known by their code designations as the section 4A tax and the section 4B tax-are commonly referred to as the Texas economic development sales taxes. Cities in counties whose population is less than 500,000 , and smaller cities in the six largest Texas counties (Bexar, Dallas, El Paso, Harris, Tarrant, and Travis), are eligible to levy the taxes.

The taxes may be imposed only if the citizens of a city approve their use in a regular election; the taxes stay in effect either for the period specified on the ballot or, if no end date is specified, until they are repealed. Each of the two taxes may be authorized in increments of one-eighth of 1 percent, up to a maximum of $1 / 2$ percent. A city may have the two taxes in force simultaneously. However, the combined rate of all local sales and use taxes, including these special taxes, may not, under Texas law, exceed 2 percent. The uses for the two taxes, as defined in the state laws creating them, are as follows:

- Section 4A. To acquire or pay for land, buildings, equipment, facilities, expenditures, targeted infrastructure and improvements for purposes related to manufacturing and industrial development.

- Section 4B. To undertake projects for quality-of-life improvements that will attract and retain primary employers. Money may be spent on land, buildings, equipment, and facilities expenditures and improvements for tourism, entertainment, recreation, athletic facilities, and parks; affordable housing; and municipal infrastructure.

1. For information about the Texas Economic Development Sales taxes, see www.window.state.tx.us/taxinfo/taxpubs/tx96_302.html. Section 4A and $4 \mathrm{~B}$ program participation, by community, can be found at the Texas Comptroller of Public Accounts website, at www.window.state.tx.us/ taxinfo/addit.html. City and county sales tax data used in this analysis came from a Freedom of Information request to that office. New and expanding investment records were provided by the state's Business and Industry Data Center through the Texas Office of the Governor, Department of Economic Development and Tourism www.governor.state.tx.us/ecodev.
Funds raised through a 4A tax are perhaps the clearest example anywhere of a dedicated pool of funds that policymakers may use at their discretion to offer incentives. Conversely, expenditures of funds raised through 4B taxes are more representative of the type of public expenditures for economic development desired by researchers and policymakers who downplay the effectiveness of direct business incentives. As of October 2007, of the more than 1,000 cities in Texas, the $4 \mathrm{~A}$ tax was in place in 222 , and the 4B tax was in place in 439. Because of the relatively high rate of participation in the programs, Texas may be an ideal case study for analyzing the effects of direct (4A) and indirect (4B) economic development incentives.

Cities adopting one or both of the taxes are required to establish a community corporation to administer the funds raised. The practical difference between the $4 \mathrm{~A}$ and $4 \mathrm{~B}$ taxes can be seen in the primary objectives of the community corporations as well as in the distribution of their spending (tables 1 and 2). According to the most recent state report on these incentives (covering fiscal 2005), job creation and job retention were the primary objectives in nearly four out of five cities that had enacted a 4A tax, compared with about half of the cities that had enacted a $4 \mathrm{~B}$ tax. Sports, recreation, and tourism development were much more likely to be the focus of $4 \mathrm{~B}$ cities. In fiscal 2005 , about 24 percent of $4 \mathrm{~A}$ tax revenues were spent on direct business incentives (such as buildings and equipment for businesses), compared with only 7 percent of $4 \mathrm{~B}$ tax revenues. In addition, almost 60 percent of 4 A revenues were

1. Objectives of economic development reported by adopting cities, by tax adopted, fiscal 2005

Percent

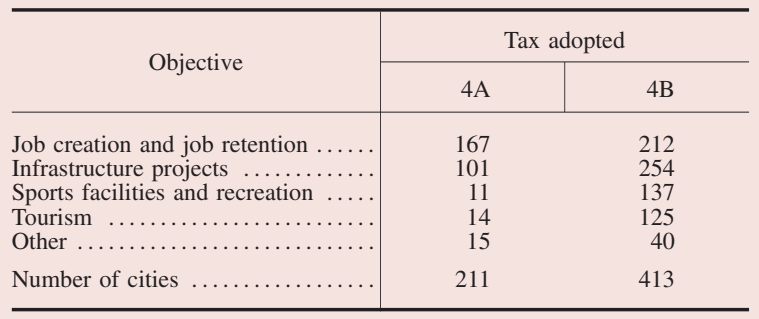

NoTE: Respondents were asked to indicate their primary objective for economic development but were allowed to identify more than one primary objective. nomic development incentives and to disclose more information about incentives. Ten years ago, fewer than half of states regularly published detailed reports on their tax expenditures; but by 2006, according to the Center on Budget and Policy Priorities, two-thirds of states were regularly preparing such reports, with most of them made available online.
State tax expenditure reports generally contain information about budget outlays; some also contain data specifically on incentives. The 2005-07 Oregon tax expenditure report, for example, discusses the state's Strategic Investment Program. Under this major incentive program, in place since 1993, firms may qualify for a 15-year exemption from property 
2. Distribution of expenditures of $4 \mathrm{~A}$ and $4 \mathrm{~B}$ funds by community development corporations, by type of expense and type of corporation, fiscal year 2005

\begin{tabular}{|c|c|c|c|c|c|c|}
\hline \multirow{2}{*}{ Type of expense } & \multicolumn{2}{|c|}{$\begin{array}{l}\text { All corporations } \\
\text { (588 cities) }\end{array}$} & \multicolumn{2}{|c|}{$\begin{array}{c}\text { Section 4A corporations } \\
\text { (208 cities) }\end{array}$} & \multicolumn{2}{|c|}{$\begin{array}{l}\text { Section 4B corporations } \\
\text { (380 cities) }\end{array}$} \\
\hline & Dollars & Percent & Dollars & Percent & Dollars & Percent \\
\hline Direct business incentives & $80,397,570$ & 14.6 & $59,118,504$ & 24.4 & $21,279,066$ & 6.9 \\
\hline Marketing and promotion & $10,054,118$ & 1.8 & $6,107,685$ & 2.5 & $3,946,433$ & 1.3 \\
\hline Debt service $\ldots \ldots \ldots \ldots$. & $112,558,737$ & 20.4 & $38,292,808$ & 15.8 & $74,265,929$ & 24.1 \\
\hline Capital costs . & $221,698,352$ & 40.2 & $97,206,877$ & 40.1 & $124,491,475$ & 40.4 \\
\hline Personnel .... & $25,879,928$ & 4.7 & $12,725,439$ & 5.2 & $13,154,489$ & 4.3 \\
\hline Administration & $25,727,296$ & 4.7 & $13,788,975$ & 5.7 & $11,938,321$ & 3.9 \\
\hline Affordable housing . & $2,429,992$ & .4 & 3,260 & .0 & $2,426,732$ & .8 \\
\hline Payments to taxing units & $31,264,632$ & 5.7 & $4,520,531$ & 1.9 & $26,744,101$ & 8.7 \\
\hline Job training $\ldots \ldots \ldots \ldots$ & $1,771,460$ & .3 & 393,192 & .2 & $1,378,268$ & .4 \\
\hline Other $\ldots .$. & $39,106,266$ & 7.1 & $10,384,887$ & 4.3 & $28,721,379$ & 9.3 \\
\hline Total & $550,888,351$ & 100.0 & $242,542,158$ & 100.0 & $308,346,193$ & 100.0 \\
\hline
\end{tabular}

Note: Components may not sum to totals because of rounding.

spent on marketing and promotion, debt service, and capital costs. Much of the spending on debt service and capital costs is likely being used on land, the single most prevalent capital asset reported by all $4 \mathrm{~A}$ and $4 \mathrm{~B}$ cities.

Ultimately, analyzing program data (data on the presence, duration, and size of the taxes) in combination with general economic data (data on announced business investments and growth in the tax base) provides information on the effects of the taxes. A starting point for such an analysis would be to compare the growth of gross business sales in adopting and non-adopting cities. The data show that the average annual rate of growth of gross sales was higher in cities that had 4A taxes in at least half the years from 1992 to 2004 than in those that did not (table 3). The same relationship held for 4B cities and non-4B cities and for cities having both taxes and those having neither; in all three data sets, the differences were statistically significant.

Another way of looking at program performance is to compare the number of announced investments by new and expanding businesses in cities that had and had not adopted the section 4A tax. Table 4 shows that by 2003 some 20 percent of eligible Texas cities had adopted the $4 \mathrm{~A}$ tax. ${ }^{2}$ Those $4 \mathrm{~A}$ cities accounted for more than 40 percent of the announcements by new businesses-the firms most likely to be affected by the presence of a develop-

2. Developing an incentive takes some time. For this reason, cities in this analysis were accorded $4 \mathrm{~A}$ status in the third year after they voted to enact the tax. ment incentive. Among 4A cities, the prevalence of newfirm announcements was most pronounced in the cities that had populations between 5,000 and 30,000. Specifically, the 86 4A cities with between 5,000 and 30,000 residents accounted for 39.8 percent of all cities of this size and 54.2 percent of new-firm announcements. Among the cities with more than 30,000 residents, the $4 \mathrm{~A}$ cities' shares were 30.5 percent of the total number of cities and 34.7 percent of new-firm announcements.

3. Average annual growth of gross sales in cities with and without 4A and 4B taxes, 1992 to 2004

\begin{tabular}{l|c|c|c}
\hline \multicolumn{1}{c|}{ City status } & $\begin{array}{c}\text { Average } \\
\text { annual } \\
\text { growth } \\
\text { (percent) }\end{array}$ & $\begin{array}{c}\text { T value for } \\
\text { difference } \\
\text { of means }\end{array}$ & Number \\
\hline 4A cities & & & \\
With tax during period ......... & 6.51 & 2.11 & 167 \\
Without tax during period ...... & 5.18 & $\ldots$ & 789 \\
4B cities & & & \\
With tax during period ......... & 6.87 & 4.01 & 255 \\
Without tax during period ...... & 4.74 & $\ldots$ & 625 \\
4A and 4B cities & & & \\
With both taxes during period .. & 8.80 & 2.88 & 48 \\
With neither tax during period ... & 4.58 & $\ldots$ & 503 \\
All Texas cities .................. & 5.48 & $\ldots$ & 1,012 \\
\hline
\end{tabular}

NotE: For cities without the tax(es), includes cities that did not have the tax during the entire period 1992-2004. For cities with the tax(es), includes only those cities that had the tax(es) for at least six years during the period 1992-2004. Excludes cities having either no population or no reported business sales in either 1992 or 2004 . taxes for new investments having an assessed value of more than $\$ 100$ million. This exemption has been used by six large semiconductor-fabrication establishments. The tradeoff for the state for the fiscal year 2005-07 biennium was $\$ 159$ million in lost property tax revenue versus a gain of $\$ 5.2$ billion in continuing investment, some $\$ 16$ million in additional property tax on related non-exempt investment, \$24 million in community service fees paid in lieu of property taxes, and unknown additional jobs, payroll, and spin-off effects. These figures provide policymakers with hard data in evaluating the incentive's efficacy.

Other groups are also making information on incentives more widely available:

- The Council for Community and Economic Re- 
4. Distribution of announcements of large business investments in cities eligible to adopt the 4A tax, 1989 to 2003

\begin{tabular}{|c|c|c|c|c|c|c|}
\hline \multirow{2}{*}{ City population and status } & \multicolumn{2}{|c|}{ Eligible cities } & \multicolumn{2}{|c|}{ Announcements of new investment } & \multicolumn{2}{|c|}{ Announcements of expansions } \\
\hline & Number & Percent of total & Number & Percent & Number & Percent \\
\hline \multicolumn{7}{|l|}{ Under 1,000} \\
\hline With tax ... & 27 & 5.7 & 2 & 40.0 & 6 & 54.5 \\
\hline Without tax & 445 & 94.3 & 3 & 60.0 & 5 & 45.5 \\
\hline Total .......... & 472 & 100.0 & 5 & 100.0 & 11 & 100.0 \\
\hline \multicolumn{7}{|l|}{1,000 to 4,999} \\
\hline With tax $\ldots$ & 107 & 24.5 & 11 & 29.7 & 14 & 40.0 \\
\hline Without tax & 330 & 75.5 & 26 & 70.3 & 21 & 60.0 \\
\hline Total . & 437 & 100.0 & 37 & 100.0 & 35 & 100.0 \\
\hline \multicolumn{7}{|l|}{5,000 to 14,999} \\
\hline With $4 \mathrm{~A}$ tax & 65 & 40.9 & 57 & 60.0 & 40 & 48.8 \\
\hline Without tax & 94 & 59.1 & 38 & 40.0 & 42 & 51.2 \\
\hline Total ........... & 159 & 100.0 & 95 & 100.0 & 82 & 100.0 \\
\hline \multicolumn{7}{|l|}{15,000 to 29,999} \\
\hline With $\operatorname{tax} \ldots$ & 21 & 36.8 & 47 & 48.5 & 41 & 34.7 \\
\hline Without tax & 36 & 63.2 & 50 & 51.5 & 77 & 65.3 \\
\hline Total .......... & 57 & 100.0 & 97 & 100.0 & 118 & 100.0 \\
\hline \multicolumn{7}{|l|}{30,000 and above } \\
\hline With tax $\ldots . .$. & 18 & 30.5 & 126 & 34.7 & 116 & 29.8 \\
\hline Without tax & 41 & 69.5 & 237 & 65.3 & 273 & 70.2 \\
\hline Total ............ & 59 & 100.0 & 363 & 100.0 & 389 & 100.0 \\
\hline \multicolumn{7}{|l|}{ All eligible cities } \\
\hline With tax $\ldots \ldots$ & 238 & 20.1 & 243 & 40.7 & 217 & 34.2 \\
\hline Without tax & 946 & 79.9 & 354 & 59.3 & 418 & 65.8 \\
\hline Percent in $4 \mathrm{~A}$ cities & 1,184 & 100.0 & 597 & 100.0 & 635 & 100.0 \\
\hline
\end{tabular}

NoTE: For this table, cities were considered to have a $4 \mathrm{~A}$ tax three years after enacting the tax. Large investments are investments worth more than $\$ 100,000$ or adding more than 100 jobs.

The analysis of the effects of the Texas economic development sales taxes is extremely preliminary, and many questions remain unanswered. For example, what other factors (such as the presence of other incentives) could influence the finding that incentives made possible by the special sales taxes are increasing business investment? Furthermore, growth of gross sales and announcements of business investment are not the only ways to measure results. What other data, such as data on employment growth or property tax revenues, could be used as proxies for the effects of the taxes? And finally, if further studies confirm that the Texas economic development sales taxes are effective tools for stimulating local economies, can the relative effect of $4 \mathrm{~A}$ and $4 \mathrm{~B}$ spending in each major category-marketing and promotion, direct business incentives, or capital costs-be determined? search (C2ER, formerly ACCRA) maintains a directory of state incentives that contains more than 1,500 records on distinct programs, many with contact information. Although this data set does not currently contain measures of the effects of incentive programs, the descriptions, some including citations of enabling legislation, are quite detailed. Policymakers can use the directory to compare incentive programs across states.

- The Census Bureau's Local Employment Dynamics database contains longitudinal data, by industry, on the formation, growth, and decline of establishments, as well as employee hirings and separations.

- The Census Bureau's American Community Survey (a new nationwide survey that will be an element of future censuses) will allow researchers to look at areas as small in size as a census tract and thereby improve researchers' ability to examine the effects of site-specific incentives.

- An increasing number of jurisdictions make available to the public tax data on real estate parcels. These databases provide such information as the market value of land and equipment_-information that helps researchers examine business activity related to incentives.

- Good Jobs First (GJF), a national policy resource center promoting corporate and government accountability in economic development, has been instrumental in making incentive programs more transparent to the public. Spurred at least by lobbying by GJF state affiliates, a dozen states now disclose information about incentives provided to specific companies. The GJF website tracks legislation relating to disclosure laws and offers model text for state and local governments. GJF also 
publishes reports on accountable development, that is, development programs that are transparent and include standards for evaluating the effectiveness of incentives.

\section{Current Thinking on Incentives}

The use of refined approaches and better data sets has improved researchers' ability to evaluate the effectiveness of specific incentive programs. But fundamental concerns remain, and some researchers have begun to write off economic development incentives as ineffective or inefficient for a host of reasons. Several arguments underlie their conclusions:

- The magnitude of any economic development incentive is generally too small to have a more-thanmarginal influence on the behavior of the typical new, relocating, or expanding firm. As a result, public resources flow to firms that do not produce any economic benefits for the area.

- Incentives are distortionary, that is, they misallocate private resources by leading firms to move to or expand in suboptimal places.

- Incentives crowd out government spending on public goods.

- The provision of incentives is a zero-sum game: gains in any one location will be offset by losses in other locations.

These arguments are not without their shortcomings, as the following discussion demonstrates.

\section{"Incentives Are Too Small to Matter"}

Fisher and Peters put forward the "too small to matter" argument in their 2004 paper "The Failures of Economic Development Incentives." 21 In their analysis, they began by assuming that (1) an incentive that reduces a firm's state and local taxes will have a statistically significant effect on that firm's economic activity and (2) this effect is represented by an elasticity of -0.3 (the "consensus" elasticity put forward by Bartik), meaning that a 10 percent tax cut for businesses will produce a 3 percent increase in investment or jobs by firms eligible for the tax cut. Applying this elasticity ratio to their research, Fisher and Peters concluded that the incentives they analyzed were responsible for only about one in ten new jobs added in the enterprise zones: "Thus the best case is that incentives work about 10 percent of the time, and

21. Peter Fisher and Alan Peters (2004), "The Failures of Economic Development Incentives," Journal of the American Planning Association, vol. 70, pp. 27-38 (Winter), http://local.law.umn.edu/uploads/ images/2222/PetersFisherFailureofEconomicIncentives.pdf. are simply a waste of money the other 90 percent." 22 They calculated that each incentive-induced job in an enterprise zone had a cost of some $\$ 42,000$ over 20 years, and argued that even though the incentives did create jobs, the cost threw doubt on the incentives' effectiveness. Of course, this conclusion is based on a "consensus" elasticity of -0.3 . If the actual elasticity were twice as large $(-0.6)$, the success rate would be doubled, meaning that the incentives would generate 20 percent of the new jobs in the enterprise zones and could be revenue enhancing (under the reasonable assumption that the incentive-induced jobs generate $\$ 21,000$ in tax revenue over 20 years, or slightly more than $\$ 1,000$ a year).

Is it possible to design an incentive that is twice as successful as the across-the-board enterprise-zone tax cuts Fisher and Peters analyzed? Proponents argue that incentives can be made more effective by targeting them to the needs of a particular region or set of firms rather than applying them broadly to a large region or a wide range of businesses. One aspect of targeting is designing an incentive in such a way as to exclude from the program those firms that would invest in the region even if they did not receive the incentive. If a large enough number of such firms can be excluded, the effectiveness of that incentive can be improved. A second aspect of targeting is specifying qualification requirements so as to reduce the possibility of extending the incentive to firms that are not likely to change their behavior even if they do receive it. Dauffenbach and Warner and Gorin studied an incentive program with such a qualification requirement: recipients of the wage subsidy provided under Oklahoma's Quality Jobs program were required to create at least 100 new jobs, making the incentive more restrictive than other incentive programs in the state. ${ }^{23}$ Both sets of researchers concluded that the targeted program was as much as 50 percent effective, that is, for every ten jobs created, five were induced by the subsidy. While the conclusions were not the statistically significant result of rigorously designed studies, the findings do merit consideration-and further study.

Although targeted incentives-such as those provided under Oklahoma's Quality Jobs program-may be more effective, targeting does raise the "but-for" question, as well as questions about fairness. To be efficient as well as effective, incentives must be

22. Fisher and Peters, "The Failures of Economic Development Incentives," p. 32.

23. Dauffenbach and Warner (2004), "Oklahoma's Ad Valorem Tax Exemptions and the Quality Jobs Act"; and Gorin, "State Economic Growth Incentives and the Oklahoma Quality Jobs Program." 


\section{Overcoming State-Tax-Related Market Distortions by Providing Local Incentives}

\section{Distortions Related to Corporate Income Tax Apportionment Formulas}

Firms that produce and sell goods or services in more than one state generally are liable, in each of those states, for taxes on some portion of their corporate profits. Many states determine the proportion of a firm's profits subject to state taxation on the basis of three equally weighted factors: the percentage of the firm's (1) property located in the state, (2) sales made to residents of the state, and (3) payroll paid to residents of the state. Uniform application of this formula across the states would result in the states, collectively, taxing all of a firm's profit exactly once, and only once. Some states, however, emphasize the sales factor in their formula by making it twice as important as the other two factors, or double-weighting it. And a few states take the so-called single-sales-factor approach, basing the proportion of profits subject to state taxation solely on the percentage of sales in the state. Emphasizing the sales factor may increase a state's attractiveness as a place for corporate expansion, but such an approach results in market distortions compared with situations where the once-standard three-factor approach are employed.

Emphasis on the sales factor magnifies the problem of "nowhere income"-income that ends up not being taxed because a corporation has so little activity in a state to which a sale is allocated. In such case, a "nexus" does not exist and, therefore, the state does not have the authority to tax the corporation. Some states have enacted a "throwback rule," under which profits from out-of-state salesprofits that are not taxed by other states-are re-allocated to the enacting state.

Such tax code differences among states play into decisions by businesses planning new facilities and operations. Suppose, for example, that a firm planning to build two identical facilities tries to decide whether to locate both facilities in state A, both in state B, or one facility in each state. Assume that the firm knows that it will sell 5 percent of its output in each state and 90 percent in the rest of the country, and that both states tax corporate income at 6 percent of profits. State A will double-weight sales, while state B weights sales at 100 percent. State B does not have a throwback rule. Table 1 shows the firm's potential tax liability under several scenarios, assuming annual profits of $\$ 100$ million.

Locating both facilities in state B would save either $\$ 5.7$ million or $\$ 2.85$ million more than locating both in state A, depending upon whether state A has a throwback rule. Locating one facility in each state would result in a tax liability either 20 or 5.5 times higher in state A than in state B. Thus, the firm might locate in state B-regardless of the

1. State tax liability for a hypothetical firm, under different scenarios

Dollars except as noted

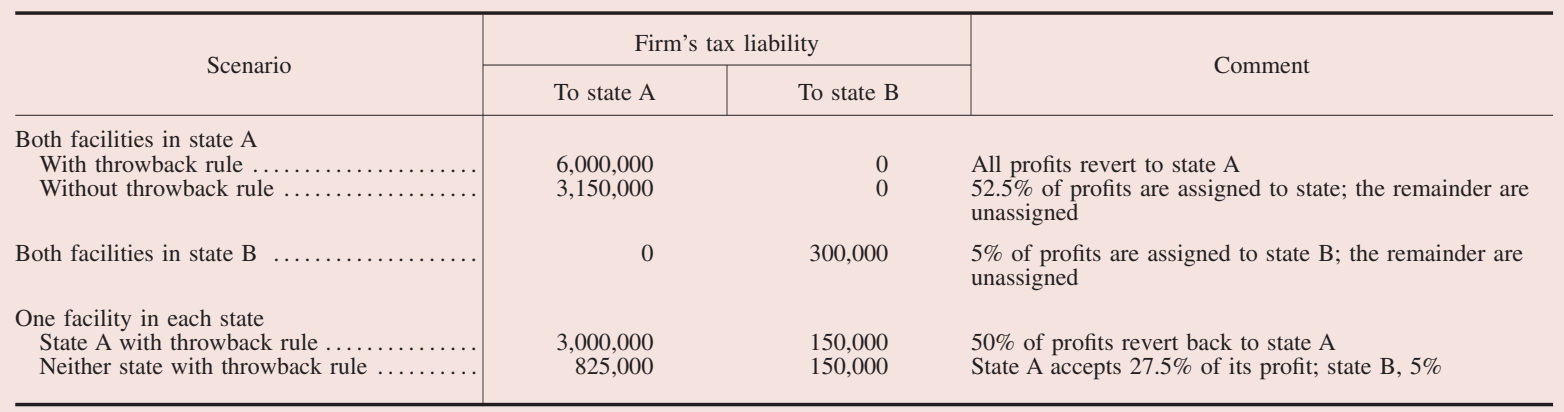

carefully targeted to exclude firms whose behavior will not be affected by the presence of the incentive. Can governments differentiate firms whose decisions about growth are likely to be affected by incentives (that is, businesses that would not locate or expand in a region "but for" the incentive) from firms whose decisions do not depend on inducements? And would governments be willing to run the political risk of offering incentives to some firms but not others (or to offer different incentives to different firms)? Or would the practice of targeting incentives be viewed as inequitable? Gorin looked at both matters in connection with the Oklahoma Quality Jobs program. In a survey of participating firms, he found that the incentive was nearly twice as important in securing the location or expansion of firms planning to add at least 100 new jobs as it was in securing the location or expansion of firms expecting to add fewer than 100 
difference in its operating costs in that state relative to its costs in state A-resulting in an inefficient allocation of resources.

State A could, to make itself a more attractive location, adopt the same apportionment formula and rules as state B, a strategy that could allow the firm to allocate its resources more efficiently; however, such a change could radically affect many additional firms in state A. Alternatively, state A might choose to use targeted incentives to overcome the distortions resulting from these differences in state tax code structures. ${ }^{1}$

\section{Distortions Resulting from Application of the Freeport Exemption}

The tax codes of most states include a "freeport exemption," which exempts from inventory tax or property tax all property that is in the state for the purpose of being assembled into other products (raw materials, for example) or for distribution (such as finished goods), provided that the property comes into the state and leaves the state within a short period (typically three or nine months). In practical terms, the exemption means that inventory in warehouses located in a state also serving as the "point of sale" generally is subject to property taxes. Thus, the freeport exemption can distort firms' decisionmaking by creating a preference to locate a warehouse or distribution center some distance from the intended market, specifically, in a location across a state border. The results of such a distortion can be seen in the proliferation of warehouses and distribution centers in Oklahoma, just north of the Oklahoma-Texas border, to serve markets around Dallas.

1. Michael Mazerov notes that at least eleven states estimated revenue loss attributable to adopting a sales-only formula. This loss of corporate income tax revenue was estimated to be above $\$ 100$ million in California, Massachusetts, and New York. See Michael Mazerov (2005), "The 'Single Sales Factor' Formula for State Corporate Taxes: A Boon to Economic Development or a Costly Giveaway?," Center on Budget and Policy Priorities report, rev. September 1, www.cbpp.org/3-27-01sfp.htm. Smaller businesses that do not benefit from the change to a sales-only formula (because all of their sales are in-state) might even fare worse if their taxes are raised to compensate for the state tax revenue lost because of the change.
2. Property tax liability for a hypothetical firm, under different scenarios

Dollars except where noted

\begin{tabular}{l|c|c|c}
\hline \multicolumn{1}{c|}{ Inventory on hand } & $\begin{array}{c}\text { Inventory } \\
\text { not eligible } \\
\text { for freeport } \\
\text { exemption } \\
\text { (percent) }\end{array}$ & $\begin{array}{c}\text { Effective } \\
\text { property } \\
\text { tax rate } \\
\text { (percent) }\end{array}$ & $\begin{array}{c}\text { Property tax } \\
\text { liability }\end{array}$ \\
\hline $\begin{array}{l}\text { Oklahoma location } \\
100,000,000 \ldots \ldots \ldots \ldots \ldots\end{array}$ & 10 & 1.10 & 110,000 \\
$\begin{array}{l}\text { Texas location } \\
100,000,000 \ldots \ldots \ldots \ldots \ldots\end{array}$ & 90 & 2.85 & $2,565,000$ \\
\hline
\end{tabular}

Suppose that a firm planning to build a warehouse to serve the Dallas area market is trying to decide whether to locate in Oklahoma or Texas. It will import its entire product from outside both states and will sell 10 percent of the product in Oklahoma and 90 percent in Texas. The effective property tax rate is 1.1 percent in Oklahoma and 2.85 percent in Texas. ${ }^{2}$ Property tax liability on inventory is calculated as:

Inventory on hand $\times$ Share of inventory not eligible for freeport exemption $\times$ Effective property tax rate.

Table 2 shows that, with an average inventory valued at $\$ 100$ million, the firm would save almost $\$ 2.5$ million annually in taxes by locating in Oklahoma-possibly more than it could save in shipping costs by locating the warehouse in the Dallas area, close to its major market. ${ }^{3}$ Should a community in the Dallas area offer the firm an incentiveperhaps a partial property tax abatement- to locate closer to Dallas, the incentive could well overcome the misallocation of resources resulting from application of the freeport exemption.

2. The Oklahoma rate in this example is the average for Ardmore and Marietta, the two largest Oklahoma communities on Interstate 35, just north of the Oklahoma-Texas border (data from the Oklahoma Department of Commerce community profiles). The Texas rate is the average of five communities: Denton and Gainesville (two cities on Interstate 35 just south of the Oklahoma-Texas border); Dallas; and two Dallas suburbs, Plano and Carrolton (data from community websites).

3. The estimated annual property tax in Texas would be $\$ 100,000,000 \times$ $90 \% \times 2.85 \%$, or $\$ 2,565,000$, compared with $\$ 100,000,000 \times 10 \% \times 1.1 \%$, or $\$ 110,000$ in Oklahoma. jobs. $^{24}$ This finding suggests that by specifying a readily identifiable criterion-number of new jobs to be added-the state was able to effectively limit participation in the incentive program. In other words, the survey data suggest that the state should be able to target the incentive. The question of political will was a different matter. Gorin noted that political considerations prompted the issuance of numerous regulatory

24. Gorin, "State Economic Growth Incentives and the Oklahoma Quality Jobs Program." proposals that would have weakened the targeting by reducing the threshold for program participation from 100 new jobs to a much lower number.

\section{"Incentives Result in Misallocation of Private Resources"}

Economic development incentives are intended to induce capital investment in a jurisdiction in which such investment might not otherwise take place. Opponents of incentives argue that such inducements 
result in the misallocation of private resources because incentives cause capital to locate in a suboptimal location, one in which the market would not naturally place the investment. Opponents further argue that this incentive-induced distortion has a negative effect on other firms in the same jurisdiction (such as higher costs for purchased inputs, as discussed by Alwang, Peterson, and Mills ${ }^{25}$ ).

However, not all incentives distort the allocation of private resources. In fact, they can be used to offset distortions resulting from differences in tax bases across jurisdictions. Some jurisdictions may rely primarily on personal income as a basis for taxation, for example, while others may rely on personal property or retail sales. Two examples (see the box "Overcoming State-Tax-Related Market Distortions by Providing Local Incentives") illustrate how variations in regional tax structures can result in the misallocation of resources and how such distortions might be overcome through carefully designed incentives. These examples, representing actual situations faced by firms and jurisdictions (though the numbers used are hypothetical), suggest that more research is needed to determine the extent to which incentives actually distort the allocation of private resources.

\section{"Incentives Given to Private Entities Crowd Out Public Spending”}

Some critics argue that spending on incentives crowds out spending on public goods and services, such as education and transportation. Burstein and Rolnick, for example, write that " $[\mathrm{w}]$ hen competition takes the form of preferential treatment for specific businesses, it misallocates private resources and causes state and local governments to provide too few public goods." 26 Fisher and Peters have echoed this sentiment, and proposed that economic development incentives be discontinued in favor of spending on infrastructure and education. ${ }^{27}$ However, quantifying the effects of spending on infrastructure and education may be just as difficult as quantifying the effects of spending on development incentives. And the presence of externalities associated with firm location (such as lower social safety net costs and higher property values

25. Alwang, Peterson, and Mills, "Assessing the Impacts of Incentives to Attract New Businesses."

26. Melvin L. Burstein and Arthur J. Rolnick (1996), "Congress Should End the Economic War for Sports and Other Businesses" Federal Reserve Bank of Minneapolis, fedgazette (January), www.minneapolisfed.org/pubs/fedgaz/96-01/opinion.cfm.

27. Fisher and Peters, "Tax and Spending Incentives and Enterprise Zones." resulting from a more robust economy) can make spending on incentives as appropriate for a government as spending on traditional public goods.

Bartik recommends that governments focus on productivity-enhancing incentives-such as job training and helping resident entrepreneurs prepare business plans-so that benefits might last longer. ${ }^{28}$ Economic development initiatives can also be used to accomplish public objectives, and even save on costs, without explicitly spending public dollars. Maine's Progressive Alliance for Careers and Training program, for instance - a well-regarded effort targeted at building up small manufacturing, health care, and information technology industries in economically depressed areas of the state-tied financial assistance for participating firms to their hiring of newly trained and dislocated workers. Other incentives that have a public purpose include the zoning incentives offered by some jurisdictions in the Washington, D.C. metropolitan area. These incentives give developers the right to build extra units of residential housing on fixed parcels of land if the developer sets aside a certain percentage of the units for affordable housing. Contrary to the criticism that incentives necessarily crowd out the spending of limited public resources for public purposes, these examples show that incentives can induce the private sector to allocate resources for a public purpose.

\section{"Incentives Are a Zero-Sum Proposition"}

Critics of incentives often invoke the "zero-sum" argument, asserting that one locality's gain in jobs or other benefits is another locality's loss. Supporters counter that even if incentives simply move jobs from one place to another and spur no additional economic activity, they can still be beneficial overall. How is it possible that the same business investment can raise overall social welfare more in one place than another? Such a situation can arise if one community values the jobs and investment more than another.

Communities' respective valuations of an opportunity for a new or expanded business can differ for a variety of reasons: economic objectives (such as higher employment rates and improved workforce skills), community goals (such as growth), and views regarding externalities (for example, town A might be more inclined to have a prison or casino than town $\mathrm{B}$, and city $\mathrm{B}$ might be more willing to accept additional noise or other adverse side effects than city A). One measure of this differing valuation or

28. Bartik, "Who Benefits from State and Local Economic Development Policies?" 
intensity of preference is willingness to pay, which has as its proxy the size of the incentive package being offered by agents for a community. In some cases, these agents may act, at least in part, on their own preferences or perceptions about community wishes. In other cases, community preferences are affirmed explicitly through the democratic process when the public has the chance to vote on general or specific incentive packages. Community preference for a project may even be confirmed or disproved after the fact by citizen response to employment opportunities.

\section{THE DISCUSSION GOING FORWARD}

The composition of economic development incentives may evolve over time in response to business and community needs and public concerns, but incentives will undoubtedly remain a tool used by policymakers to stimulate local and state economic development. Good public policy requires that the details of incentive packages be disclosed and that the effectiveness of incentives be measured. Policymakers can then be held accountable for their decisions on the basis of evidence rather than politics. New databases allowing more-accurate analysis are becoming available, and new data sources are beginning to make public the details of incentive packages. The research described in this article shows the ways in which data and methods have improved over the past ten years. Furthermore, the studies suggest that incentives can be effective in certain situations, and also buttress the case for further research that makes use of the new data and investigative tools. 